\title{
HMPG's long-time torch bearers sally forth
}

Two academic stalwarts who have led the transformation of SAMA's general medical journals (SAMJ and CME) and its 10 specialist medical journals, last month left the helm of their sturdy purpose-crafted business ship, the Health and Medical Publishing Group (HMPG).

Professor Dan Ncayiyana, an obstetrician/ gynaecologist, thus becomes the secondlongest serving SAMJ Editor (20 years and the first black editor), after its founder Dr W Darley-Hartley (1884 - 1889 and 1903 1926). His deputy, Professor JP van Niekerk, a radiologist and the prime facilitator in setting up the HMPG - an independent, arm's-length business entity run on behalf of SAMA - was Managing Editor for 11 years. Both will keep an eye on their beloved ship in much-reduced roles, Ncayiyana as Editor Emeritus and Van Niekerk as Managing Editor. The new Editor-in-Chief, Janet Seggie, an ad hominem Professor in UCT's Faculty of Health Sciences, takes over as the first-ever woman in the post. The exiting duo had rich, varied and intertwining careers. Ncayiyana was appointed Deputy Vice-Chancellor at UCT (while continuing as SAMJ Editor) when Van Niekerk was Dean of Medicine there. Ncayiyana was persuaded by the then Minister of Education,

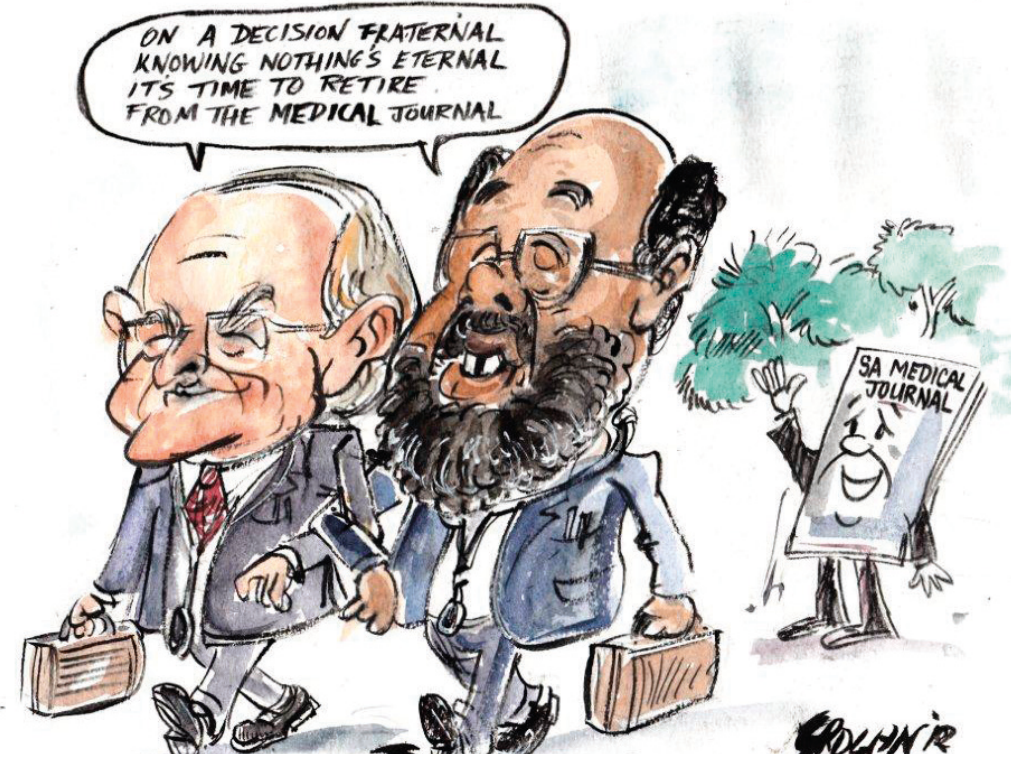

Professor Kader Asmal, to merge Durban's ML Sultan Technikon and Natal Technikon into a new non-racial institution of which he became Vice-Chancellor, amid much campus turbulence which he defused with great skill and the requisite discipline. This took up most of his time. The then chief of the SAMA Publications Committee-run journal stable, Peter Roberts, approached Van Niekerk (who had by then been shifted sideways and appointed Dean Emeritus of Medicine by then UCT Chancellor, Dr Mamphela Ramphele) to help manage the ship.

Van Niekerk, a former SAMA President, Treasurer and long-time Chair of its Publications Committee, had already overseen 
the transition of the SAMJ from a weekly to a monthly publication, and came on board as Deputy Editor and then as Managing Editor. He had long seen the need to 'professionalise' SAMA's publishing operation into a selfstanding enterprise, so he commissioned UCT's Graduate School of Business to help craft a way forward. After three years, during which Peter Roberts resigned to join his cleric wife in the United Kingdom, SAMA 'bought' the idea of an HMPG contracted to a large business-to-business publishing house, Cape Media, which set up a company called Media Outsourcing to handle its new partner.

Despite greater print and online costs, a CPD programme and additional journals, SAMA members today pay a significantly lesser portion of their subscription fees towards the HPMG while enjoying additional free, stateof-the-art online access benefits, including fast-tracked manuscripts, mostly championed and directed by Van Niekerk, who effectively became the CEO when Roberts left.

The HMPG is today an autonomous (wholly SAMA owned) business entity with its own board of directors, enjoying major cost- and skills-efficient synergies with Cape Media while retaining its gravitas as a scholarly/academic enterprise, regularly challenging conventional ideas and practice through its independent editorials and news coverage. Both departing men have been at the heart of medical education in South Africa - Ncayiyana pioneering rural-based medical mentoring and training while Dean of Medicine and Vice-Chancellor at the former Unitra University (University of Transkei, now Walter Sisulu University) and Van Niekerk chairing Education and the Foreign Qualified Doctors Committees of the Health Professions Council of South Africa and deputising the Impaired Doctors committee. They will continue to review SAMJ scientific articles and be on HMPG 'call' as it enters a new era, bolstered by their work and dedication.

\section{Chris Bateman}

chrisb@hmpg.co.za

S Afr Med J 2012;102(12):907-908.

DOI:10.7196/SAMJ.6474 